\title{
SPATIAL DETERMINISM AND TERRITORIAL PUBLIC ACTION IN FRANCE: CHALLENGES AND EVOLUTIONS
}

\author{
Grégory BUSQUET \\ University of Paris Ouest Nanterre - La Défense, France
}

\begin{abstract}
The French policy called "politique de la ville" that was institutionalized in the 80 s, aimed to manage social contemporary problems of low cost housing built by the state in the $50 \mathrm{~s}$ and $60 \mathrm{~s}$ at the peripheries of cities following grand schemes ("grands ensembles"). Based on the study of the actors of this policy since its beginnings and of its underlying ideologies, this article shows that these districts are managed at present following the same patterns of thinking as the ones that engendered them. Since the 60s, the criticism of these grand schemes of low cost housing carried on by slogans such as "living environment" and "urban self-management" determined an answer from public authorities. However, I argue that these responses used different terms but continued in fact on same track. An ideology of spatial determinism and an ideal of social mix span all French urban policies since the $50 \mathrm{~s}$, while the idea of urban participation appears and then fades away. These ideologies were and continue being inherent in understanding the relations between space and society.
\end{abstract}

Key Words: urban space, living environment, urban policies, France

\section{Introduction}

This paper explores the relationships between urban space and politics. In 1973 Henri Lefebvre defined urban space as being a political space, that is not only a political product, but also a support, an instrument and a challenge for contradictory strategies and for confrontations (Lefebvre, 1973). I am focusing in particular on political contemporary space in France.

We begin by presenting the French case and some concrete examples of the policy called "politique de la ville" that was implemented since the $80 \mathrm{~s}$, including the political ideas that made it possible. Then we focus on the status and on the exact place that urban space occupies in public action and in the thinking of the various actors - politicians, urban planners, architects... We therefore discuss the issues of urban ideology (Busquet 2007a; 2007b; 2009) and its consequences.

To put it differently, we address the question if political contemporary representations consider space as a mere instrument - as a means - or rather as a real challenge for social change. Therefore I describe the way space is used as a tool in contemporary public action, starting from the representations of the relationships between space and society, dating back in the $70 \mathrm{~s}$, that led to the "politique de la ville" of the 80 s.

First of all, we explain briefly the French "politique de la ville", its history and the context that witnessed its birth. In the second section of this paper, I identify the stakeholders that defended this policy and I analyze their ideas. This allows the study of the emergence of new slogans, such as "urban self-management" ("autogestion urbaine") and "living environment" ("cadre de 
vie") in the 60 s-70s.

In the third section, I present the transfer of these ideas into action. I concentrate on the study of the ideology underlying this public policy, on the evolutions and adaptations of these systems of ideas in front of reality and practice and on their social and spatial consequences.

\section{From "grands ensembles" to "politique de la ville"}

The policy called "politique de la ville" appeared in France after the political left-wing wined the national elections, in the 1981. It is a multi-ministerial policy that essentially aimed to enhance positive aspects of "difficult" suburbs and districts, by managing the districts called "grands ensembles" planned by the former regimes. "Grands ensembles" are grand schemes of low cost housing, built from scratch and in a voluntary manner by the state, in the period of economic growth starting from the 50s up to the 70s (Dufaux, Fourcaut 2004).

In this period the French state has built a very large number of dwellings in city peripheral areas that were not yet urbanized and that lacked urban utilities, pursuing a quantitative objective. If we simplify, the goal was to build fast a large number of dwellings at the lowest cost possible, in order to house work force, made up especially of immigrants and rural migrants attracted by the needs of industry. Large "grands ensembles" appeared and multiplied in this context (Dufaux, Fourcaut 2004). They were created and reproduced employing standardized construction techniques functionalist and rationalistic design principles inspired by the Charter of Athens. We should also remind the fact that these housing complexes were supposed to allow the mixing of middle class and workers.

However, starting from the end of the 60 s, in France especially the media started to talk about the "trouble of the suburbs" ("mal des banlieues") referring to these neighborhoods: difficulties in cohabitation between different social classes, due to population distribution and housing policies (Chamboredon, Lemaire 1970), and a kind of boredom engendered by the functionalistic organization of space, by the lack of services, of leisure infrastructures - or, to put it shortly - lack of attractivity (Lefebvre 1960).

As a consequence, in 1973 the French state stopped building "grands ensembles" ("Circulaire Guichard", after the minister of construction Olivier Guichard). Moreover, during the 70s, the majority of the middle class inhabitants left these areas in order to acquire private houses, this tendency being encouraged by a new policy supporting individual housing. In parallel, the economic crisis of the 70s and the growth of unemployment struck these areas particularly hard, since they were increasingly inhabited by poor people living in buildings that grew old quickly.

On top of all this, in the beginning of the $80 \mathrm{~s}$, the first riots of young people took place in the "grands ensembles" neighborhoods. It was in this general context that "politique de la ville" first appeared in the 70s, in an incipient phase, that was later institutionalized, in the $80 \mathrm{~s}$ and $90 \mathrm{~s}$.

Starting from the 80s, "politique de la ville" was divided into several components (Dubedout 1983). A first branch targeted specific "populations" in order to control crime in districts designated as being "sensitive". This type of action that could be called police-enforced or repressive was followed by a socio-economic component in which emphasis was placed on education, public services, tax exemption for companies, in order to encourage employment in these districts. The third component was particularly urban and spatial. It aimed to link these suburbs to the city centers and to open up certain districts ${ }^{1}{ }^{\text {. }}$. This involved an intervention on 
the physical space as well as the revival of the social mix principle that was already present during the construction of "grands ensembles". From that moment on the departure of the middle class had to be prevented by making these areas more attractive and more secure (for the population, as well as for companies).

Shortly put, facing the obsolescence of these large social housing areas, in the last thirty years, the French state tried to repair, more or less successfully, what it has produced for two decades, since the 50 s up to the 70 s, in a former context of economic growth.

So the French "politique de la ville" consists of a series of measures introduced in order to provide a remedy to social and economic problems, that are understood as isolated and confined in space: therefore this type of territorialized public action is resolutely spatial. And this characteristic leads to certain hidden effects, that I shall point out further on.

But for a more detailed insight into this issue, we need to explore the complex sum of stakeholders that supported "politique de la ville" as well as their ideas.

\section{The actors of "politique de la ville" and their ideas}

At its beginnings, this policy was promoted by a small team of high civil servants and experts, graduates of the "Ecole des ponts" and of the National School of Administration (ENA), members of the elected local governments, NGO representatives, stakeholders coming from the social movement scene as well as of architects, to whom the authorities had granted the mission of reconnecting suburbs and cities ${ }^{2)}$. Most of the actors who took part in the creation of this policy are still carrying it out at present.

But from an ideological point of view, "politique de la ville" was created in the 80s through an infusion of dissenting ideas in the state apparatus, a process that had been taking place since the 70 s.

While it is true that an ideology guided "politique de la ville" at its origins, like all ideologies, this one was also constructed in opposition to another ideology (Mannheim 1929). But in this situation, I claim that we are facing continuity.

In order to explain this, we need to go back to the 50 s and 60 s, when urban policies revealed a desire to reinforce the role played by the state in town planning and in the field of construction. This period was dominated by the state intervention policy applied by General De Gaulle based on a rationalist urban ideology. The large suburban areas and the type of housing they proposed - "grands ensembles" -, were based on the spatialist ideology, which is a sort of spatial determinism over social activity. This issue was studied by Jean-Pierre Garnier (Garnier 2001) and Yves Chalas (Chalas 1997). This instrumentalist ideology is especially present in the case of architects and planners who conceive acting upon physical space as a way to transform society: "in order to change life and society, it is enough to change the city". Colonizations as well as the former socialist systems in Central and Eastern Europe (who

1) In the beginning of the 80 s were created: for deliquency prevention in these districts, The National Council for Delinquency Prevention ("Conseil national de prevention de la délinquance" - CNPD); in order to remedy spatial problems, the "Mission Banlieue 89"; and against social problems, the Commission of Social Development of Suburban Districts ("Developpement social des quartiers" - DSQ). In 1988 all these public bodies were brought together in a multi-ministerial authority ("Délégation inter-ministerielle à la ville" - DIV), and, later on, in an unique Ministry ("Ministère de la ville"), in 1990.

2) Roland Castro and Michel Cantal-Dupart, from the mission « Banlieue 89 ». 
intended to create the "new man") were an experimental field for this ideology that, just as most utopias, requires strong and often authoritarian political power in order to be applied. In the French case it went hand in hand with the interests of a Gaullist power who whished to modernize France, its economy and society.

This spatial determinist ideology integrated ideas of technical and architectural progress, of improved lifestyle and comfort, and combined these positive aspects with the need to offer accommodation to the entire French population.

We can undoubtfully apply here the theory of Habermas stating that technical ideas, modernization and ideology are entangled (Habermas 1968). Technical ideas and the city are thus conceived as determining the evolution of society and as synonymous to the idea of modernity (Castells 1972).

In the French case, this ideology developed on the premise of a prosperous society, and of a context in which slums, shantytowns and housing shortage were due to disappear. The ideology of modernity and of a strong central government has therefore seized urban issues and imposed its specific contents (Fourcaut 2002).

However, in opposition to the essentially quantitative approaches (the fast construction of a large number of housing units during the housing crisis), critics developed more social arguments concerning the "grands ensembles", that were more qualitative and referred to social unrest, degradation of social life, tedium, and improper housing. Some of the first critics of these housing complexes were sociologists and, as a consequence, urban sociology began to develop in France starting from the end of the 60s (Amiot, 1986). Based on the themes of "living environment" and "quality of everyday life", it was particularly developed by Marxists and by public figures such as Henri Lefebvre (Lefebvre 1947; 1962; 1968a; 1970b).

In parallel, social and urban movements were multiplying in France and they also started to contest the mono-functionality and the lack of community facilities of "grands ensembles". These themes started a great deal of debate among the French "Second Left". This was a noncommunist movement promoting self-management, that introduced in the 70 s the urban issue into French institutional and political life, through bodies such as the Unified Socialist Party ("Parti Socialiste Unifié"- PSU), the French labor union called "Confédération française démocratique du travail" (CFDT), and the "Groupes d'Action Municipale" (Busquet 2007a).

So French urban sociologists, members of the Second Left, participants in the social movements, as well as some of the left-wing catholic civil servants, began discussing about "urban self-management". From the 60s on, these groups advocated for residents and city's users to be taken into consideration in decisions and urban projects, along with their hopes and desires and, consequently, with their contributions. The idea of participation or of selfmanagement was therefore developed in the $70 \mathrm{~s}$ in response to the city planning practices of the preceding Gaullist period that had been technocratic and state-controlled. This idea is the heir of "urban self-management" advocated in the May 1968 movement against the same grievances and that Henri Lefebvre is the theoretician in France. "Le Droit à la ville" (The Right to the City, meaning the right of inhabitants to "centrality", to "take part and to be informed", especially concerning the dominated class) (Lefebvre, 1968a) was claimed by Lefebvre in the same time as "self-management of urban life" (Lefebvre 1970a). These are moreover the slogans took over by urban struggles of the 70 s, especially those concerning collective facilities in the new "grands ensembles", quality of life in these districts, or the pure contestation of "grands ensembles". 
But the end of the 60 s and the 70 s were in France also the years when the term "living environment" ("cadre de vie") appeared. It was related to that of "quality of life" in the cities and it was taken over by the "urban middle class" who protested against existing urban social life (Dagnaud 1978; Bidou-Zachariasen 1982). This term does not refer only to man's physical environment but also to his social environment.

"Living environment" commissions appeared afterwards in the left-wing political parties (PSU, French communist party, Socialist Party, etc.). The emergence of this term in political discourses denotes the new concern for the extensions of the dwelling, that are: its environment, neighborhood life, and, more generally, to urban issues from a more qualitative point of view (e.g. segregation, social life, esthetical qualities etc.). But "living environment" shows above all a change in scale in addressing social issues in the city, henceforth focusing on the individual and on the family. This approach is present in social sciences as well as in the field of politics.

Later on, throughout the 70 s, the successive right-wing French governments chose to increasingly rely on the participation of citizens and to go back to a qualitative town planning that was closer to "human scale" (D'Arcy, Prats 1985). The presidency of Valéry Giscard d'Estaing (1974-1981) opened thus the way to a series of laws meant to improve "the living environment" and living conditions, the quality of architecture, to reduce the scale of cityplanning and even to interfere in urban space from a social point of view.

In this way, these measures broke away from the preceding period and recovered the slogans of the left wing and of the social movements. This led to the implementation in 1977 of the first "housing and social life" programs ("Habitat et vie sociale" - HVS), which are the first experiences of "Politique de la ville" that the left wing will institutionalize in the 80s.

However, we should keep in mind that certain promoters of the Second Left had advocated these procedures previously, in 1973: they had participated in the HVS focus group set up by the government, aiming to improve social life in "grands ensembles" areas.

In parallel, in 1974 a large number of Second Left members joined the new Socialist Party. It was as a result of this presence that, participation, self-management and new town planning ideas have been integrated into the party discourse, a fact that later on influenced considerably the decentralization of public policies of the $80 \mathrm{~s}$. Above all, they promoted the "politique de la ville", that the socialists introduced following their accession to power at the national level.

Therefore, we can argue that "politique de la ville" appeared at the convergence of different legacies coming from: leftist principles such as self-management, catholic thinking - through the intermediary of high civil servants (civil engineers, graduates of the ENA), of the Second Left, as well as urban sociology and social urban movements.

Consequently an "urbanization" of the discourses and of the standpoints of the French Left is produced by the convergence of these new stakeholders and of these new themes that emerge in the context of the social urban movements of the 60s and 70s: the idea of "urban participation" - that maintains a close relationship to that of self-management promoted by the PSU and by a part of the extreme Left - and the idea of "living environment", closely related to that of "everyday life", employed by sociologists. These themes go together with a strengthening of contestations, as well as with emergence of more qualitative claims as opposed to more quantitative previous ones. But, above all, they allow for the urban space to acquire a special place in political thinking, by consolidating its presumed role in solving social urban problems. In this way, this perspective distorts the nature of urban space as well as its 
potential: urban space is not only perceived as the support and the ground of public policies or of their contestations, but it acquires a first degree qualitative status from a social point of view, as well as political, i.e. in terms of power and democracy.

At this point, I still need to discuss the ideology of "politique de la ville", its application, its social effects and its evolution.

\section{The ideology of "politique de la ville" its application and evolution}

Starting with the "politique de la ville" of the 80 s, the urban territory became a challenge for political discourses and for public action.

But already in the 70s urban issues stated being dealt with at the local level of the neighborhood (Genestier 1999). Problems and their solutions became increasingly qualitative. A critique of authoritarian town planning led to another form of spatial determinist ideology. By assimilating local space as a social issue, this urban ideology implied that space was a challenge and determined collective identities which were generally defined in relation to their living environment, e.g. people living in shantytowns or in "grands ensembles", etc. This logically led through to the leading idea of "politique de la ville".

The spatial component of this policy, that l've already mentioned, has led to the programs Mission Suburbs 89 ("Banlieue 89") which, at the beginning of the 80 s, promoted the reconnection of a certain number of territories, as well as urban renewal, housing improvement, renovation, demolition of housing blocks and towers. Furthermore, this policy led to the recent program of the National Agency in charge of Urban Renewal ("Agence nationale pour la rénovation urbaine" - ANRU).

This program sets forth the demolition of the most dilapidated housing estates and their replacement with new ones, comprising more diverse types of housing units (detached homes and collective housing). However, in practice, as the former "grands ensembles" are destroyed, their residents are being relocated to social housing elsewhere. Hence the ideal of social mix has disappeared. In accordance with its underlying spatial determinist ideology, more emphasis is placed on spatial segregation than on the structural causes of exclusion. However, it is not enough to raze the old housing in order to solve social problems, that in this way are relocated elsewhere. The method applied here means to demolish and to find the simplest solutions available: pure spatial determinist thinking has thus been translated into public action, in a similar way as at the time these grands ensembles had been built. If in the 60 s, by means of urbanism and architecture we wanted to change society, for about thirty years now, in France, we want to heal or to treat society by means of taking action on space. The agenda has changed but the way in which space, its relations with society and to social groups are conceived, remained the same.

However, even when it deals with space - as in the case of urban renewal - or when it doesn't, for thirty years "politique de la ville" has been translating social problems in spatial terms. Districts have been targeted in relation to zoning principles and this aspect has recently been reinforced by the concept of "priority geography" ("géographie prioritaire").

Taking as a starting point the morphological indicators (e.g. the presence of "grands ensembles"), as well as social and economic indicators (i.e. school dropout rate, crime, percentage of young people, of unemployed, of single-parent families etc.), precise territories have been pointed out and circumscribed. Then the state put forward the necessary funding in order to take action in these precise areas. It therefore targeted "neighborhoods" and 
"problematic populations". It sought to localize and to translate social problems in spatial terms, thus representing an expression of spatial determinism. Moreover, the result of this practice was the stigmatization of certain populations in relation to their location and to their sociodemographical characteristics, and even more, regarding ethnic characteristics, as the French sociologist Sylvie Tissot pointed out (Tissot 2007).

By means of urban renewal and zoning, spatial determinism has been perpetuated, and moreover reinforced, in "politique de la ville", even if, as we have shown here, it was already present when the zones treated by this policy had been conceived.

Similarly, we have already seen that social mix through housing, part of the "politique de la ville" principles, have been already present, at least in theory, in previous urban policies.

However, the ideas of self-management or of participation, that have been dominant throughout the 70s and 80s (Hatzfeld 2005), have gradually disappeared, mainly after the 90s, in spite of a continuity of the actors present since the beginning of this policy. Since then, we have been witnessing a reinforcement of the role played by the state, as it multiplied measures and funds. In the $80 \mathrm{~s}$, "politique de la ville" was based on a contract between the state and local authorities. Therefore, the projects were generated by local initiative and were based on negotiations at different levels and on different scales (Gaudin 1993; Le Galès 1995). A "democratization" at the local level thus developed in parallel to an "urbanization" of politics and policies and to a "politicization" of urban issues (Busquet 2007a).

Later on, after more riots and since the creation of "Ministère de la Ville" in 1990, a bureaucratic mechanism that strictly regulated all initiatives was put into practice. Nowadays, and especially since the creation of the National Agency for Urban Renewal (ANRU) in 2003, an extremely centralized administration is distributing public finances (Epstein 2005). The policy "politique de la ville" is nowadays conceived at the national level and is afterwards passed further on to local administrations. Ready-made solutions are proposed and the administrations pick one or another, without any diagnosis of specific problems.

Along with all this, since the $80 \mathrm{~s}$, a change in the discourses dealing with "grands ensembles" has occurred. Initially, "politique de la ville" was pointing out the existent qualities of these "difficult neighborhoods" and their potential, based on the competences of the inhabitants, through the idea of participation. Nowadays, the discourse is more and more compassionate and negativist: these neighborhoods are presented as being socially homogeneous (Tissot 2007). In a certain way, this idea goes along with a certain homogenization among "grands ensembles" and among their problems, since local contexts, be they social, economic or spatial, are being neglected.

To sum up all this, three ideologies underlie urban policies of the $60 \mathrm{~s}$, as well as the following "politique de la ville", even if they take up different forms: spatial determinism, social mix or the importance of state intervention. Opposing this last idea, the promoters of "politique de la ville" have proposed self-management, and afterwards the idea of participatory democracy. However this innovative idea did not last long.

\section{Conclusions}

A first couple of conclusions concern "politique de la ville" and territorial public action, and a third one regards urban ideology and space. 
Firstly, concerning "politique de la ville", I can argue that the aim of urban policy is at present to remedy problems related to the town planning heritage dating back to the Gaullist period, and to respond to the slogans and criticisms that dominated the end of the 60 s and the urban social movements of the 70s. If left wing and urban sociological criticism have had any influence whatsoever on this policy, then it has been only indirectly. Their influence was conveyed by concepts and slogans, such as "participation" and "quality of everyday life", that were imposed by urban sociologists, the Second Left and by urban social movements. Moreover, an illdefined set of stakeholders and slogans, rather than a set of ideas set a link between this criticism and its answers.

Secondly, state intervention, in accordance with the wishes of local elected representatives, targeted territories rather than people. Thus spatial categorization of social groups and social categorization of spaces justify and legitimize public action. But this approach runs the risk of producing an amalgam, mixing people and built environment. This has, of course, as a consequence a strengthening of stigmatization of "sensitive" districts, or of districts presenting the risk of riots, that includes a stigmatization of the inhabitants of these districts.

Finally, concerning urban ideology, despite changing and evolving discourses and methods, a continuity can be noticed between urban policies of the 60 s and "politique de la ville". The choice to treat social aspects through spatial features persists, even if the final objective is no longer the same. Space has therefore a dialectic status: it is always criticized and it always becomes the salutary tool in discourses and practices. As political instrument, urban space crystallizes contemporary political thinking and becomes a means for intervening on the social issues: in the past, by means of building activities, and nowadays, by razing former dwelling complexes. We can therefore ask ourselves if "politique de la ville" isn't actually trying to manage the inherited "grands ensembles" by the same kind of thinking that engendered them. Spatial determinism, as well as social mix - principles that underlay the construction of grands ensembles from the 50 s up to the 70 s - are thus supposed to cure their problems, as well as to remedy contextual outcomes, such as riots, segregation and anomie of these suburban neighborhoods.

\section{References}

AMIOT, M. (1986), Contre l'Etat, les sociologues. Eléments pour une histoire de la sociologie urbaine en France (1900-1980), Paris, éditions de l'EHESS.

BIDOU-ZACHARIASEN, Catherine (1982), Les modes de vies des nouvelles couches moyennes: modèle culturel et recherche d'identité , in : Espaces et modes de vie. Proceedings of the Symposium of Dourdan, Paris, Plan construction et habitat, Mission de la recherche urbaine, june 1982: 63-69.

BUSQUET, G. (2007a), Idéologie urbaine et pensée politique dans la France de la période 1958-1981, PhD thesis in Urban studies, Institut d'urbanisme de Paris / Paris XII-Val de Marne.

BUSQUET, G. (2007b.), L'idéologie et l'espace urbain dans les années 60-70: le cas du discours du Parti socialiste unifié, in : VIALA Laurent, VILLEPONTOUX Stéphane (dir.), Imaginaire, territoires, sociétés. Contribution à un déploiement transdisciplinaire de la géographie sociale, Montpellier, Université Paul-Valéry-Montpellier III: 311-324.

BUSQUET, G. (2009), Le spatialisme et la pensée politique progressiste sur la ville, in : BAUDIN Gérard, BONNIN Philippe, Faire territoire aujourd'hui, Paris, Editions Recherches: 281 -299 . 
CASTELLS, M. (1972), La Question urbaine, Paris, Anthropos, 1975.

CHALAS, Y. (1997), Les périphéries dans le discours urbanistique, in : CHALAS Yves, Urbanité et périphérie. Connaissance et Reconnaissance des territoires contemporains, Paris, ministère du Logement, Plan Construction et Architecture (Programme "Evolution des territoires contemporains $»)$.

CHAMBOREDON, J.C., LEMAIRE, Madeleine (1970), Proximité spatiale et distance sociale: les grands ensembles et leur peuplement, Revue française de sociologie, $\mathrm{n}^{\circ} \mathrm{XI}-1$, Paris.

DAGNAUD, Monique (1978), Le Mythe de la qualité de la vie et la politique urbaine en France. Enquête sur l'idéologie urbaine de l'élite technocratique et politique (1945-1975), Paris, EHESS.

D'ARCY, F., PRATS, Y. (1985), Les politiques du cadre de vie, in: GRAWITZ Madeleine, LECA François (dir.), Traité de science politique, vol. 4, Les Politiques publiques, Paris, PUF.

DUBEDOUT, H. (1983), Ensemble, refaire la ville. Rapport au Premier ministre du Président de la Commission nationale pour le développement social des quartiers, Paris, La Documentation Française. Paris, Créaphis.

DUFAUX, Fr., FOURCAUT, Annie (dir.) (2004), Le Monde des grands ensembles, $n^{\circ} 11$.

EPSTEIN, R. (2005), Gouverner à distance. Quand l'Etat se retire des territoires, Esprit

FOURCAUT, Annie (2002), Trois discours, une politique?, Urbanisme $\mathrm{n}^{\circ} 332$, «Le grand ensemble, histoire et devenir ", January-February 2002: 39-45.

GABEL, J. (1974), Idéologies, vol. 1: Recueil de textes partiellement extraits de diverses revues et publications, 1948 - 1972, Paris, Anthropos.

GARNIER, J-P. (2001), Urbaniser pour dépolitiser : la rhétorique du spatialisme et du localisme, Ecole thématique "Violence, consensus, sécurité ", Ecole Nationale Supérieure Lettre et sciences humaines de Lyon, 12-16 november 2001, Wednesday, the 13th November of 2001 : « Le débat contemporain », Lyon.

GAUDIN, J-P. (1993), Les nouvelles politiques urbaines, Paris, PUF.

GENESTIER, Ph. (1999), Le sortilège du quartier : quand le lieu est censé faire lien, Les Annales de la recherche urbaine, $n^{\circ} 82$.

HABERMAS, J. (1968), Technik und Wissenschaft als Ideologie, Suhrkamp Verlag, Frankfurt am Main.

HATZFELD, Hélène (2005), Faire de la politique autrement. Les expériences inachevées des années 1970, Rennes, ADELS, Presses Universitaires de Rennes.

LEFEBVRE, H. (1947), Critique de la vie quotidienne, vol. 1: Introduction, Paris, L'Arche, 1958 ; Critique de la vie quotidienne; vol. 2 : Fondements d'une sociologie de la quotidienneté, Paris, L'Arche, 1962.

LEFEBVRE, H. (1960), Les nouveaux ensembles urbains (un cas concret: Lacq-Mourenx), Revue française de sociologie, re-edited in Du rural à l'urbain, Paris, Anthropos, 1970.

LEFEBVRE, H. (1968a), Le Droit à la ville, Paris, Le Seuil, 1974.

LEFEBVRE, H. (1968b), La Vie quotidienne dans le monde moderne, Paris, Gallimard.

LEFEBVRE, H. (1970a), La Révolution urbaine, Paris, Gallimard.

LEFEBVRE, H. (1970b), Du rural à l'urbain, Paris, Anthropos.

LEFEBVRE, H. (1973), Le Droit à la ville II : Espace et politique, Paris, Anthropos, 2000.

LE GALES, P. (1995), Du gouvernement urbain à la gouvernance urbaine, Revue française de sciences politiques, $n^{\circ} 1$.

MANNHEIM, K. (1929), Idéologie et utopie, Paris, Librairie Marcel Rivière et Cie, 1956. 
Grégory BUSQUET

TISSOT, Sylvie (2007), L'Etat et les quartiers. Genèse d'une catégorie de l'action publique, Paris, Seuil.

Initial submission, November 10, 2010

Revised submission, February 3, 2011

Final acceptance, April 28, 2011

Correspondence: University of Paris Ouest Nanterre - La Défence, Department of Sociology, Paris, France. E-mail: gregory.busquet@paris-valdeseine.archi.fr 